\title{
Economics of Milk Production in Lactating Murrah Buffaloes Supplemented with Mustard Oil
}

\author{
Aayush Yadav", G.P. Lakhani, Biswajit Roy, Bhavna Aharwal, \\ Sudipta Ghosh and R.P.S. Baghel
}

Department of Livestock Production and Management, College of Veterinary Science and Animal Husbandry, NDVSU, Jabalpur, M.P., India

*Corresponding author

\begin{tabular}{|l|}
\hline K e y w o r d s \\
Murrah, Mustard oil, \\
$\begin{array}{l}\text { Economics, Milk } \\
\text { yield, FCM yield }\end{array}$ \\
\hline Article Info \\
\hline Accepted: \\
04 October 2018 \\
Available Online: \\
10 November 2018
\end{tabular}

\section{A B S T R A C T}

The present study was conducted at Livestock farm, Adhartal, College of Veterinary Science \& A.H., N.D.V.S.U., Jabalpur (M.P.). A total of 12 advance pregnant Murrah buffaloes of identical parity and similar previous lactation yield were selected 21 days prepartum and randomly assigned to two groups of six animals each; CON as control with basal diet and MO as mustard oil supplementation @ $200 \mathrm{ml} / \mathrm{animal} /$ day upto 90 days post-partum to study the effect on economics of milk production in lactating Murrah buffaloes. The daily milk yield was recorded individually twice at 6 A.M. and 4 P.M. and the milk fat per cent was studied using ultrasonic auto milk analyser. Results revealed reduced feed cost (Rs.) per kg 6\% FCM yield in MO (19.03) than CON (20.25) and highest return of Rs. 270.82 per animal per day in MO. The net return in comparison to CON was Rs. 45.94 in MO which suggests that supplementation of MO is economically feasible. The additional benefits are due to significant $(\mathrm{p}<0.05)$ improvement in average daily milk yield by 8.10 per cent and milk fat content by 9.14 per cent in MO as compared to CON. The 6\% FCM yield were significantly $(\mathrm{p}<0.05)$ higher in MO followed by CON. In conclusion, $\mathrm{MO}$ provided more economic returns to the dairy farm.

\section{Introduction}

Nutrition plays crucial role in growth, reproduction and production of animals. Out of total production cost, 60 per cent is accounted for feed and fodders. Therefore, in today's economy, it becomes imperative to get maximum out of the feed fed (Thomas and Sastry, 2012). As parturition approaches, a progressive decrease in dry matter intake (30\%) in the last three weeks of gestation and about 90 per cent during last five to seven days occurs before calving (Ingvartsen and Andersen, 2000). After calving, most of energy gets diverted for colostrum and milk synthesis as a result of which animal goes into negative energy balance (NEB) (Walsh et al., 2007) for first 8 to 12 weeks. Therefore to prevent NEB, cereal grains and fats play a valuable role as alternate sources of energy in the ration of dairy animals. To counter affect the demerits of higher levels of concentrate feeding as acidosis and decline in concentration of milk fat; supplementing fat in 
the diet has become a standard practice to fulfil the energy requirements of dairy cows. Supplementation of fat might increase the cost of feeding but net return per animal may also increase due to increase in milk yields and milk fat apart from its positive effect on reproduction and health of animal (Mane et al., 2017). The cost of feeding per litre milk production is a significant factor in governing the economic viability of livestock sector which must be reduced by adopting new measures in the ration formulation. This leads to search for sources that are also easily available and economically feasible. In this context, dietary fat as whole flaxseed (Cavalieri et al., 2005), mustard oil (Kathirvelan and Tyagi, 2009), soybean oil (Thakur and Shelke, 2010) and sunflower oil (Dai et al., 2011) has been used for long in many developing countries for high producing dairy animals. Among these oils, mustard oil is cheaper source of fat supplements and therefore, in view of the above facts, the present investigation was conducted to assess the economics of milk production in lactating Murrah buffaloes supplemented with mustard oil.

\section{Materials and Methods}

\section{Proposed work}

The proposed work was conducted on twelve advance pregnant Murrah buffaloes for a period of six months at Livestock Farm, Adhartal, College of Veterinary Science \& A.H., Nanaji Deshmukh Veterinary Science University, Jabalpur (M.P.). The study was conducted during 21 days pre-partum to 90 days post-partum after the adaptation period of 10 days. The climate of the region is light tropical, sub humid with a seasonal variation in temperature ranging from 6.6 to $41.9^{\circ} \mathrm{C}$ and an average annual rainfall of $1,415 \mathrm{~mm}$. The animals were selected on the basis of similarity in body weight, age, parity $\left(1^{\text {st }}\right.$ to $3^{\text {rd }}$ ) and previous lactation yield. The animals were randomly assigned into two groups as control (CON) and mustard oil (MO), based on feeding of different feed substances (Table $1)$.

\section{Feeding regime}

Experimental animals were stall fed and maintained in semi-intensive system of housing. All The experimental animals were fed total mixed ration according to their body weight and production as per ICAR (2013). The chaffed green fodder (berseem / sorghum / maize), and wheat straw were offered ad libitum and concentrate consisting of 18 per cent crude protein and 70 per cent total digestible nutrients was offered at a scale of 1 $\mathrm{kg}$ per $2.0 \mathrm{~kg}$ milk production along with maintenance ration as per routine practices at the farm. Measured quantity of mustard oil $(200 \mathrm{ml})$ was mixed daily in concentrate of supplemented group (MO) at the time of feeding. Half of the total required quantity of feed was offered daily at morning 5.30 am and rest amount offered in the afternoon $3.00 \mathrm{pm}$. The water was kept available to animals round the clock.

\section{Parameters studied were}

\section{Feed intake and dry matter (\%)}

Daily intake of concentrate, straw and green fodder was recorded for individual animals. Weighed quantities of concentrate, straw and green fodder were offered to animals and the leftover was collected next day in the morning and weighed. The leftover was subtracted from the initial feed supplied to know the actual amount of feed consumed by the animal. The representative samples of concentrate mixture and roughage were taken in moisture cup and kept in hot air oven at $100 \pm 2^{\circ} \mathrm{C}$ for $24 \mathrm{hrs}$ and dry matter was calculated as follows: 
Dry weight of sample $(\mathrm{g})$

Dry matter $(\%)=$----------------------- $\mathrm{x} 100$

Fresh weight of sample (g)

\section{Milkfat (\%)}

The representative milk samples of individual animals were collected from the milking bucket after complete milking of the individual animal and analysed for milk fat percentage at fortnightly intervals throughout the experimental period using Lacto Plus (Ultrasonic auto milk analyzer, Netco Pvt. Ltd.).

Milk yield and fat corrected milk (FCM) yield

Animals were hand milked twice a day for the first five days and ninety days after calving i.e., at 6 am and $4 \mathrm{pm}$ for recording of colostrum and milk yield individually. Milk obtained from two times milking was combined together to get the actual milk yield of the buffaloes for that day. The milk yield was recorded at fortnightly intervals throughout the experimental period.For the conversion of whole milk into 6 per cent FCM yield, the equation derived by Rice (1970) was used. The FCM yield was calculated at fortnightly intervals during 90 days lactation period.

$$
(0.4 \times \text { MY }(\mathrm{kg})+15 \text { x Fat }(\mathrm{kg}))
$$

6 per cent $\mathrm{FCM}$ yield $(\mathrm{kg})=$

\section{3}

\section{Economics of milk production}

The economics of milk production was calculated on the basis of 6percent FCM yield.

\section{Statistical analysis}

Data were analyzed using ANOVA, described by Snedecor and Cochran (1994) and the means showing significant differences in the ANOVA table were compared using the Duncan Multiple Range Test (Steel and Toorie, 1980).

\section{Results and Discussion}

Mustard oil is extracted from the seeds of Brassica juncea, B. nigra and B. hirta belonging to family Brassicaceae and order Brassicales. It has 12 per cent of saturated fat, 60 per cent of monounsaturated and 21 per cent of polyunsaturated fat. The major unsaturated fatty acids (\%) in mustard oil are the polyunsaturates; alpha-linolenic acid (3) and linoleic acid (15) and the monounsaturates; oleic acid (12) and erucic acid (42). It also contains the saturated fatty acids (\%); stearic acid (1.12), myristic acid (1.39) and palmitic acid (3.75). The characteristic pungent flavour of mustard oil is due to allyl isothiocyanate (Anonymous, 2018).Mustard oil have been known as the cheaper and most abundant potential fat source which can increase flexibility of diet and makes possibility for cheaper animal production.

\section{Dry matter intake (DMI; Kg/animal/day)}

The detail performance of the lactating Murrah buffaloes is presented in table 2. The overall average daily DMI was $19.60 \pm 0.44$ and 19.41 \pm 0.48 in CON and MO, respectively and was numerically higher in CON. There was no significant difference in the average DMI between the groups. The percent improvement in DMI from calving to 3 months in CON and MO was 26.96 and 17.10, respectively whereas; in comparison to $\mathrm{CON}$, per cent decrease in $\mathrm{MO}$ was 0.96 . Continuous increase in the DMI was observed in lactating Murrah buffaloes throughout the study period.

The non-significant findings are in agreement with the findings of Sarwar et al., (2004); 
AlZahal et al., (2008); Huang et al., (2008); Mele et al., (2008); Suksombat and Chullanandana (2008); Sultana et al., (2008); Ye et al., (2009); Sirohi et al., (2010); Tyagi et al., (2010); Dai et al., (2011); Khalil et al., (2012); Mudgal et al., (2012); Shelke et al., (2012); Altenhofer et al., (2014); Khare et al., (2014); Kirovski et al., (2015) and Sharma et al., (2016).Numerically, MO experienced lowest DMI which is supported by the findings of Chouinard et al., (1997); Shingfield et al., (2006); Ben-Salem and Bouraoui (2008) and Kathirvelan and Tyagi (2009). The animals in NEB consume more DMI because of craving for more nutrients to support higher milk production. This was not seen in the present study as animals were not high yielders and the required energy for supporting milk production was met through the diet. This may be a possible hypothesis for no significant changes in DMI. Also, short feeding period of 12 weeks or small amount of oil supplementation may be another reason. Further findings reveal that pungent flavour of mustard oil may be a reason for numerically lowest DMI in MO.

\section{Daily milk yield (MY; lit)}

The detail performance of the lactating Murrah buffaloes is presented in table 2. The overall average daily MY (lit.) was found to be significantly $(\mathrm{p}<0.05)$ higher in $\mathrm{MO}$ (8.54 \pm 0.06$)$ than CON (7.90 \pm 0.06$)$, respectively. The overall average daily MY varied significantly between the groups and the per cent increase in daily MY from calving to 3 months period in $\mathrm{CON}$ and $\mathrm{MO}$ was 22.00 and 27.69, respectively; however MO showed 8.10 per cent increase in daily MY as compared to CON. The fortnightly average daily MY increased up to $4^{\text {th }}$ fortnight and thereafter decreased gradually.

Similar findings of increase in milk yield by fat supplements were reported by McNamara et al., (2003); Barley and Baghel (2009); Kathirvelan and Tyagi (2009); Tyagi et al., (2010); Dai et al., (2011); Khalil et al., (2012); Shelke et al., (2012); Gowda et al., (2013); Madan et al., (2013); Vahora et al., (2013); Otto et al., (2016); Sharma et al., (2016) and Singh et al., (2016). The gradual decrease in fortnight average daily MY from $5^{\text {th }}$ fortnight onwards was in agreement with the findings of Veira et al., (2001); Altenhofer et al., (2014) and Rodrigues (2017).

Milk production is generally increased by the inclusion of fat in basal ration probably due to improvement in the efficiency of energy utilization. The highest average per cent increase in daily MY was 8.10 in this study than 7.27 and 7.30 reported by AlZahal et al., (2008) and Gowda et al., (2013), respectively which further indicates that pre and postpartum feeding was more effective in eliciting the higher milk production response than feeding alone in early lactation. The increase in average daily milk yield in MO is believed to be due to improved reproductive performances; whereas less MY in CON is credited to the non-availability of fat supplements in the ration.

\section{Milk fat (\%)}

The detail performance of the lactating Murrah buffaloes is presented in table 2. The overall average fat per cent varied significantly $(\mathrm{p}<0.05)$ between the groups and the values were higher in MO (7.52 \pm 0.01$)$ followed by CON $(6.89 \pm 0.01)$. The average fat per cent in milk has increased throughout the study period in both the groups. The per cent increase in milk fat from calving to 3 months period in $\mathrm{CON}$ and $\mathrm{MO}$ was 16.32 and 5.48; however milk fat per cent was significantly higher in MO by 9.14 per cent in comparison to CON. Further, results reveal higher fat yield $(\mathrm{kg})$ in $\mathrm{MO}(0.64)$ followed by CON (0.54). 


\section{Table.1 Experimental diet were fed as follows}

\begin{tabular}{|c|l|c|l|}
\hline S. No. & Groups & Number of animals & Treatments \\
\hline 1. & CON & 6 & Basal diet \\
\hline 2. & MO & 6 & $\begin{array}{l}\text { Basal diet + Mustard oil supplementation } \\
\text { @ } 200 \mathrm{ml} \text { per animal per day }\end{array}$ \\
\hline
\end{tabular}

Table.2 Fortnightly average daily dry matter intake (DMI; kg/animal/day), daily milk yield (lit.), milk fat

$(\%)$ and 6 per cent FCM yield (Kg) in lactating Murrah buffaloes (Mean \pm SE) in different treatment groups

\begin{tabular}{|c|c|c|c|c|c|c|c|c|}
\hline \multirow[t]{2}{*}{ Fort. } & \multicolumn{2}{|c|}{ DMI } & \multicolumn{2}{|c|}{ Daily Milk Yield } & \multicolumn{2}{|c|}{ Milk fat } & \multicolumn{2}{|c|}{ FCM yield } \\
\hline & $\mathrm{CON}$ & MO & $\mathrm{CON}$ & MO & $\mathrm{CON}$ & MO & $\mathrm{CON}$ & MO \\
\hline 1 & $16.80 \pm 0.71$ & $17.77 \pm 1.38$ & $6.23 \pm 0.17$ & $6.50 \pm 0.16$ & $6.19 \pm 0.02$ & $7.30 \pm 0.01$ & $6.95 \pm 0.18$ & $8.07 \pm 0.20$ \\
\hline 2 & $18.07 \pm 0.57$ & $18.48 \pm 1.19$ & $8.10 \pm 0.10$ & $8.50 \pm 0.12$ & $6.70 \pm 0.04$ & $7.45 \pm 0.01$ & $9.49 \pm 0.11$ & $10.70 \pm 0.16$ \\
\hline 3 & $20.32 \pm 1.25$ & $19.10 \pm 0.98$ & $8.51 \pm 0.11$ & $9.20 \pm 0.08$ & $6.96 \pm 0.01$ & $7.50 \pm 0.01$ & $10.23 \pm 0.15$ & $11.64 \pm 0.10$ \\
\hline 4 & $20.37 \pm 1.26$ & $20.04 \pm 0.96$ & $8.81 \pm 0.13$ & $9.64 \pm 0.08$ & $7.10 \pm 0.01$ & $7.55 \pm 0.04$ & $10.73 \pm 0.16$ & $12.24 \pm 0.10$ \\
\hline 5 & $20.90 \pm 0.99$ & $20.25 \pm 1.42$ & $8.20 \pm 0.13$ & $9.10 \pm 0.12$ & $7.19 \pm 0.01$ & $7.62 \pm 0.05$ & $10.08 \pm 0.15$ & $11.64 \pm 0.16$ \\
\hline 6 & $21.33 \pm 0.78$ & $20.81 \pm 1.22$ & $7.60 \pm 0.12$ & $8.30 \pm 0.05$ & $7.20 \pm 0.01$ & $7.70 \pm 0.02$ & $9.34 \pm 0.14$ & $10.69 \pm 0.07$ \\
\hline$\overline{\text { Avg. }}$ & $19.60 \pm 0.44$ & $19.41 \pm 0.48$ & $7.90^{a} \pm 0.06$ & $8.54^{b} \pm 0.06$ & $6.89^{a} \pm 0.01$ & $7.52^{b} \pm 0.01$ & $9.47^{\mathrm{a}} \pm 0.08$ & $10.84^{b} \pm 0.08$ \\
\hline
\end{tabular}

Table.3 Economics of mustard oil supplementation on milk production in lactating Murrah buffaloes

\begin{tabular}{|l|c|c|}
\hline \multicolumn{1}{|c|}{ Attributes } & CON & MO \\
\hline Amt. (kg) of concentrate/animal/day & 6.88 & 6.90 \\
\hline Amt. (kg) of dry roughage/animal/day & 10.80 & 9.28 \\
\hline Amt. (kg) of green roughage/animal/day & 19.50 & 19.53 \\
\hline Cost (Rs.) of concentrate/animal/day & 116.41 & 116.75 \\
\hline Cost (Rs.) of dry roughage/animal/day & 36.39 & 31.27 \\
\hline Cost (Rs.) of green roughage/animal/day & 39.00 & 39.06 \\
\hline Cost (Rs.) of mustard oil/animal/day @ Rs. 95.3/lit. & - & 19.06 \\
\hline Total feed cost (Rs.)/animal/day & 191.80 & 206.14 \\
\hline Average 6 per cent FCM yield (kg)/animal/day & 9.47 & 10.84 \\
\hline Return (Rs.) from 6 per cent FCM yield & 416.68 & 476.96 \\
\hline produced/animal/day @ Rs.44/lit & & 19.03 \\
\hline Cost of feed (Rs.)/kg 6 per cent FCM yield & 20.25 & 270.82 \\
\hline Return (Rs.)/animal/day & 224.88 & roughage- \\
\hline Cost of ingredients: Concentrate- Rs.16.92/kg; Dry roughage- Rs.3.37/kg; Green & & \\
\hline Rs.2.00/kg; Mustard oil- Rs.19.06/200 ml; Milk - Rs.44.00/lit. & & \\
\hline
\end{tabular}

The present findings are in orthodox with the findings of Mele et al., (2008); Barley and Baghel (2009); Shelke et al., (2012); Madan et al., (2013); Vahora et al., (2013); Kirovski et al., (2015); Moncada-Lainez and LiangChou (2016); Otto et al., (2016); Sharma et al., (2016) and Thul et al., (2017).In the current study, increase in fat per cent in milk 
in MO may be attributed to the availability of more fatty acids for absorption in intestine and these fatty acids are directly incorporated in milk fat after absorption from intestine, leading to increase in milk fat, which is in confirmation with the findings of Shelke et al., (2012).

\section{Fat corrected milk yield (FCM; kg)}

The detail performance of the lactating Murrah buffaloes is presented in table 2. The overall average 6 per cent FCM yield $(\mathrm{kg})$ varied significantly between the groups and the values were statistically higher in $\mathrm{MO}$ $(10.84 \pm 0.08)$ followed by CON $(9.47 \pm 0.08)$. The per cent increase in FCM yield from calving to 3 months period in $\mathrm{CON}$ and $\mathrm{MO}$ was 34.39 and 32.47; however MO showed 14.47 per cent increase in FCM yield as compared to CON. The fortnightly average 6 per cent $\mathrm{FCM}$ yield $(\mathrm{kg})$ increased up to $4^{\text {th }}$ fortnight and thereafter decreased gradually.

The findings are consistent with the findings of Sultana et al., (2008) in Holstein cows supplemented with calcium salts of soybean oil and linseed oil fatty acids @ 1 per cent (DMB); Vahora et al., (2013) in buffaloes supplemented with bypass fat @ $20 \mathrm{~g} / \mathrm{kg}$ milk yield and Sharma et al., (2016) in Murrah buffaloes supplemented with prilled fat @ 100 and $150 \mathrm{~g} / \mathrm{d}$ during pre and post-partum period, respectively. The increase in 6 per cent FCM yield is credited to the higher average daily MY and milk fat per cent in the supplemented group over control group.

\section{Economics of milk production}

The effect of feeding of mustard oil on average cost of milk production for experimental period of three months is presented in table 3. On an average, the total feed cost (Rs.) per animal per day during the experimental period in $\mathrm{CON}$ and $\mathrm{MO}$ was 191.80and 206.14, respectively. The average 6per cent FCM yield $(\mathrm{kg})$ in $\mathrm{CON}$ and $\mathrm{MO}$ was 9.47 and 10.84, respectively. The total average cost (Rs.) of feed per kg 6per cent FCM yield was calculated as 20.25 and 19.03 for CON and MO, respectively. Reduction in feed cost (Rs.) per kg 6 per cent FCM yield in comparison to $\mathrm{CON}$ was 1.22 in $\mathrm{MO}$. The per cent reduction in feed cost per kg6per cent FCM yield in MO was 6.02 in comparison to CON. Based on the cost of feed, return (Rs.) per animal per day was calculated as 224.88 and 270.82 in $\mathrm{CON}$ and MO, respectively. The per cent return per animal per day in MO was20.43 in comparison to CON. The net return (Rs.) per animal per day in $\mathrm{MO}$ was 45.94 in comparison to $\mathrm{CON}$.

Similar findings have shown to give additional profit of Rs.34.5/- per buffalo per day (Naik et al., 2009); 36/- per buffalo per day (Parnerkar et al., 2011); 46.91/- per buffalo per day (Shelke and Thakur, 2011); 11.60/- per cow per day (Gowda et al., 2013); 15.53/- per buffalo per day (Vahora et al., 2013); 23.70/- per animal per day (Amrutkar et al.,2014); 11.05/- per animal per day (Grewal et al.,2014); 50/- per cow per day (Singh et al., 2014); 94.46/- per cow per day (Yadav et al., 2015); 62.07/- per cow per day (Mane et al., 2017) and 127.49/- per cow per day (Parihar et al., 2018).

The present findings may be attributed to the supplementation of mustard oil in the ration which increased 6 per cent FCM yield, suggesting that supplementation is economically feasible.

The present findings indicate that $\mathrm{MO}$ significantly $(p<0.05)$ improved average daily milk yield, milk fat per cent and 6 per cent FCM yield as compared to CON. Besides improvement in production performances, supplementation of MO has reduced feed cost per $\mathrm{kg} 6$ per cent FCM yield which resulted in 
higher returns based on feed cost per animal per day in MO followed by CON, suggesting that this technology is economically feasible and can be used for efficient milk production.

\section{References}

Altenhofer, C., M. Spornraft, H. Kienberger, M. Rychlik, J. Herrmann, H.H.D. Meyer and Viturro, E. 2014. Effects of rapeseed and soybean oil dietary supplementation on bovine fat metabolism, fatty acid composition and cholesterol levels in milk. Journal of Dairy Research, 81: 120-128.

AlZahal, O., N.E. Odongo, T. Mutsvangwa, M.M. Or-Rashid, T.F. Duffield, R. Bagg, P. Dick, G. Vessie and McBride, B.W. 2008. Effects of monensin and dietary soybean oil on milk fat percentage and milk fatty acid profile in lactating dairy cows. Journal of Dairy Science, 91(3): 1166-1174.

Amrutkar, S.A., S.S. Thakur and Pawar, S.P. 2014. Economics of supplementing rumen protected methionine and lysine in the ration of lactating crossbred cows. Indian Journal of Animal Nutrition, 31: 14-19.

Anonymous. 2018. Mustard oil. https://bit.ly/2Io9qzn. Accessed on 24 June, 2018.

BAHS. 2017. Basic Animal Husbandry Statistics. Online http://www.dahd.nic.in

Barley, G.G. and Baghel, R.P.S. 2009. Effect of bypass fat supplementation on milk yield, fat content and serum triglyceride levels of Murrah buffaloes. Buffalo Bulletin, 28(4): 173-175.

Ben-Salem, M. and Bouraoui, R. 2008. Effects of calcium salts of palm fatty acids and protected methionine supplementation on milk production and composition and reproductive performances of early lactation dairy cows. International Journal of Dairy Science, 3: 187-193.

Cavalieri, F.B., G.T. Santos, M. Matsushita, H.V. Petit, L.P. Rigolon, D. Silva, J.A. Horst, L.C. Capovilla and Ramos, F.S. 2005. Milk production and milk composition of dairy cows fed Lac100® or whole flaxseed. Canadian Journal of Animal Science, 85: 413-416.

Chouinard, P.Y., V. Girard and Brisson, G.J. 1997. Lactational response of cows to different concentrations of calcium salts of canola oil fatty acids with or without bicarbonates. Journal of Dairy Science, 80: 1185-1193.

Dai, X.J., C. Wang and Zhu, Q. 2011. Milk performance of dairy cows supplemented with rapeseed oil, peanut oil and sunflower seed oil. Czech Journal of Animal Science, 56(4): 181191.

Gowda, N.K.S., A. Manegar, A. Raghavendra, S. Verma, G. Maya, D.T. Pal, K.P. Suresh and Sampath, K.T. 2013. Effect of protected fat supplementation to high yielding dairy cows in field condition. Animal Nutrition and Feed Technology, 13: 125-130.

Grewal, R.S., N. Tyagi, J.S. Lamba, C.S. Ahuja and Saijpaul, S. 2014. Effect of bypass fat and niacin supplementation on the productive performance and blood profile of lactating crossbred cows under field conditions. Animal Nutrition and Feed Technology, 14: 573-581.

Huang, Y., J.P. Schoonmaker, B.J. Bradford and Beitz, D.C. 2008. Response of milk fatty acid composition to dietary supplementation of soy oil, conjugated linoleic acid or both. Journal of Dairy Science, 91(1): 260-270.

ICAR. 2013. Nutrient requirements of cattle and buffalo. Indian Council of Agriculture Research, New Delhi, India. 
Ingvartsen, K.L. and Andersen, J.B. 2000. Integration of metabolism and intake regulation: A review focusing on periparturient animals. Journal of Dairy Science, 83(7): 1573-1597.

Kathirvelan, C. and Tyagi, A.K. 2009. Conjugated linoleic acid content of milk from buffaloes fed a mustard oil based diet. International Journal of Dairy Technology, 62(2): 141-146.

Khalil, W.A., M.A. El-Harairy and Abul-Atta, A.A. 2012. Impact of dietary protected fat (Magnapac) on productive and reproductive performances of lactating Holstein cows. Journal of Animal and Poultry Production, 3(10): 437-450.

Khare, A., R.P.S. Baghel, R.S. Gupta, S. Nayak, V. Khare, A. Patil, R. Sharma, R. Tomar and Singh, V.P. 2014. Milk production of indigenous cattle fed supplements of mustard oil cake or azolla meal (Azolla filiculoides). Livestock Research for Rural Development, 26(4): 1-10.

Kirovski, D., B. Blond, M. Katic, R. Markovic and Sefer, D. 2015. Milk yield and composition, body condition, rumen characteristics and blood metabolites of dairy cows fed diet supplemented with palm oil. Chemical and biological technologies in agriculture, 2 : 1-5.

Livestock Census. 2012. $19^{\text {th }}$ livestock census Ministry of Agriculture, Department of Animal Husbandry Dairying and Fisheries. Government of India.

Madan, J., N. Saxena, C. Mohan, R. Kumar, K. Kumar and Lal, D. 2013. Field study on protected fat feeding during summer season on milk yield and milk composition in buffaloes. Haryana Veterinary, 52: 93-95.

Mane, S.H., S.D. Mandakmale, C.A. Nimbalkar, D.H. Kankhare and Lokhande, A.T. 2017. Economics of feeding protected protein and protected fat on crossbred cattle. Indian Journal of Animal Research, 51(6): 1080-1085.

McNamara, S., T. Butler, D.P. Ryan, J.F. Mee, P. Dillon, F.P. O’Mara, S.T. Butler, D. Anglesey, M. Rath and Murphy, J.J. 2003. Effect of offering rumen-protected fat supplements on fertility and performance in springcalving Holstein Friesian cows. Animal Reproduction Science, 79: 45-56.

Mele, M., A. Serra, A. Buccioni, G. Conte, A. Pollicardo and Secchiari, P. 2008. Effect of soybean oil supplementation on milk fatty acid composition from Saanen goats fed diets with different forage: concentrate ratios. Italian Journal of Animal Science, 7: 297-311.

Moncada-Lainez, M. and Hsia, L.C. 2016. Effect of tea leaf and soybean oil supplementation on milk composition of dairy cows. Journal of Research in Agriculture and Animal Science, 3(11): 1-6.

Mudgal, V., R.P.S. Baghel, A. Ganie and Srivastava, S. 2012. Effect of feeding bypass fat on intake and production performance of lactating crossbred cows. Indian Journal of Animal Research, 46: 103-104.

Naik, P.K., S. Saijpaul, A.S. Sirohi and Raquib, M. 2009. Lactation response of cross bred dairy cows fed indigenously prepared rumen protected fat - A field trial. Indian Journal of Animal Sciences, 79: 1045-1049.

Otto, J.R., P. Nish, R.O. Balogun, M.J. Freeman, B.S. Malau-Aduli, P.A. Lane and Malau-Aduli, A.E.O. 2016. Effect of dietary supplementation of pasturebased primiparous Holstein Friesian cows with degummed crude canola oil on body condition score, live weight, milk yield and composition. Journal of Applied Animal Research, 44(1): 194200. 
Parihar, S., G.P. Lakhani, R.P.S. Baghel, S. Ghosh and Roy, B. 2018. Changes in productive and reproductive performance of indigenous lactating cattle fed on mustard oil and molasses supplementation. International Journal of Livestock Research, 8(1): 166-170.

Parnerkar, S., D. Kumar, S.S. Shankhpal and Thube, M. 2011. Effect of feeding bypass fat to lactating buffaloes during early lactation. In: Proceedings of $14^{\mathrm{th}}$ Biennial Conference on Livestock Productivity Enhancement with Available Feed Resources, Pantnagar, 3-5, November 2011, Animal Nutrition Society of India, pp 111-112.

Rice, V.A. 1970. Breeding and improvement of farm animals. McGraw Hill Book Co., Bombay, India.

Rodrigues, J.P.P. 2017. Soybean oil supplementation for cattle: Effects on in vitro digestion, dairy cattle performance, and milk fat composition. D.Sc. thesis, Federal University of Vicosa, Vicosa, Minas Gerais, Brazil.

Sarwar, M., M.A. Khan and Nisa, M. 2004. Influence of ruminally protected fat and urea treated corncobs ensiled with or without corn steep liquor on nutrient intake, digestibility, milk yield and its composition in Nili-Ravi buffaloes. Asian-Australasian Journal of Animal Science, 17: 86-93.

Sharma, S., M. Singh, A.K. Roy and Thakur, S. 2016. Effect of pre-partum prilled fat supplementation on feed intake, energy balance and milk production in Murrah buffaloes. Veterinary World, 9(3): 256259.

Shelke, S.K. and Thakur, S.S. 2011. Economics of feeding rumen protected fat and protein to lactating Murrah buffaloes. Indian Journal of Animal Nutrition, 28: 278282.

Shelke, S.K., S.S. Thakur and Amrutkar, S.A. 2012. Effect of feeding protected fat and proteins on milk production, composition and nutrient utilization in Murrah buffaloes (Bubalus bubalis). Animal Feed Science and Technology, 171: 98-107.

Shingfield, K.J., C.K. Reynolds, G. Hervas, J.M. Griinari, A.S. Grandison and Beever, D.E. 2006. Examination of the persistency of milk fatty acid composition responses to fish oil and sunflower oil in the diet of dairy cows. Journal of Dairy Science, 89(2): 714732.

Singh, M., G. Yadav, A.K. Roy and Thakur, S. 2016. Productive performance and metabolic hormonal profile in cows supplemented with prilled fat. Indian Journal of Traditional Knowledge, 15(2): 292-296.

Singh, M., J.P. Sehgal, A.K. Roy, S. Pandita and Rajesh, G. 2014. Effect of prill fat supplementation on hormones, milk production and energy metabolites during mid-lactation in crossbred cows. Veterinary World, 7: 384-388.

Sirohi, S., T.K. Walli and Mohanta, R.K. 2010. Supplementation effect of bypass fat on production performance of lactating crossbred cows. Indian Journal of Animal Sciences, 80(8): 733-736.

Snedecor, G.W. and Cochran, W.G. 1994. Statistical Methods, $7^{\text {th }}$ Edn., Oxford \& IBH Publishing Co., New Delhi, India.

Steel, R.G.D. and Torrie, J.H. 1980. Principles and procedures of statistics. A biometrical approach, $2^{\text {nd }}$ Edn., Mc Graw Hill Book Co., New York, USA.

Suksombat, W. and Chullanandana, K. 2008. Effects of soybean oil or rumen protected conjugated linoleic acid supplementation on accumulation of conjugated linoleic acid in dairy cows milk. Asian-Australasian Journal of Animal Sciences, 21(9): 1271-1277.

Sultana, H., T. Ishida, T. Shintaku, S. Kanda and Itabashi, H. 2008. Effect of feeding 
Ca-salts of fatty acids from soybean oil and linseed oil on c9, t11-CLA production in ruminal fluid and milk of Holstein dairy cows. Asian-Australasian Journal of Animal Sciences, 21(9): 1262-1270.

Thakur, S.S. and Shelke, S.K. 2010. Effect of supplementing bypass fat prepared from soybean acid oil on milk yield and nutrient utilization in Murrah buffaloes. Indian Journal of Animal Science, 80(4): 354-357.

Thomas, C.K. and Sastry, N.S.R. 2012. Dairy Bovine Production, $2^{\text {nd }}$ rev. Edn., Kalyani Publishers, New Delhi, India.

Thul, M.R., P.S. Oberoi, A. Kumaresan, D.S. Gonge, P. Bharti, K.P. Japheth and Chandrasekar, T. 2017. Effect of mustard oil supplementation during transition period on milk composition and calf birth weight in Murrah buffaloes. International Journal of Livestock Research, 7(7): 132-139.

Tyagi, N., S.S. Thakur and Shelke, S.K. 2010. Effect of bypass fat supplementation on productive and reproductive performance in crossbred cows. Tropical Animal Health and Production, 42: 1749-1755.

Vahora, S.G., S. Parnerkar and Kore, K.B. 2013. Productive efficiency of lactating buffaloes fed bypass fat under field conditions: Effect on milk yield, milk composition, body weight and economics. Iranian Journal of Applied Animal Science, 3(1): 53-58.

Veira, D.M., L.L. Charmley, E. Charmley and Lee, A.J. 2001. The effect of feeding soybean oil to mid lactation dairy cows on milk production and composition and on diet digestion. Canadian Journal of Animal Science, 81: 425-428.

Walsh, R.B., D.F. Kelton, T. Duffield, K.E. Leslie, J.S. Walton and LeBlanc, S.J. 2007. Prevalence and risk factors for postpartum anovulatory condition on dairy cows. Journal of Dairy Science, 90: 315-324.

Yadav, G., A. Roy and Singh, M. 2015. Effect of prilled fat supplementation on milk production performance of crossbred cows. Indian Journal of Animal Nutrition, 32: 133-138.

Ye, J.A., C. Wang, H.F. Wang, H.W. Ye, B.X. Wang, H.Y. Liu, Y.M. Wang, Z.Q. Yang and Liu, J.X. 2009. Milk production and fatty acid profile of dairy cows supplemented with flaxseed oil, soybean oil, or extruded soybeans. Acta Agriculturae Scandinavica, 59(2): 121-129.

\section{How to cite this article:}

Aayush Yadav, G.P. Lakhani, Biswajit Roy, Bhavna Aharwal, Sudipta Ghosh and Baghel, R.P.S. 2018. Economics of Milk Production in Lactating Murrah Buffaloes Supplemented with Mustard Oil. Int.J.Curr.Microbiol.App.Sci. 7(11): 363-372. doi: https://doi.org/10.20546/ijcmas.2018.711.045 